\title{
Protein-bound solute removal during extended multipass versus standard hemodialysis
}

\author{
Sunny Eloot ${ }^{1 *}$, Wim Van Biesen ${ }^{1}$, Mette Axelsen², Griet Glorieux', Robert Smith Pedersen ${ }^{{ }^{\wedge}}$ and James Goya Heaf ${ }^{4}$
}

\begin{abstract}
Background: Multipass hemodialysis (MPHD) is a recently described dialysis modality, involving the use of small volumes of dialysate which are repetitively recycled. Dialysis regimes of 8 hours for six days a week using this device result in an increased removal of small water soluble solutes and middle molecules compared to standard hemodialysis (SHD). Since protein-bound solutes (PBS) exert important pathophysiological effects, we investigated whether MPHD results in improved removal of PBS as well.
\end{abstract}

Methods: A cross-over study (Clinical Trial NCT01267760) was performed in nine stable HD patients. At midweek a single dialysis session was performed with either 4 hours SHD using a dialysate flow of $500 \mathrm{~mL} / \mathrm{min}$ or 8 hours MPHD with a dialysate volume of $50 \%$ of estimated body water volume. Blood and dialysate samples were taken every hour to determine concentrations of p-cresylglucuronide (PCG), hippuric acid (HA), indole acetic acid (IAA), indoxyl sulfate (IS), and p-cresylsulfate (PCS). Dialyser extraction ratio, reduction ratio, and solute removal were calculated for these solutes.

Results: Already at 60 min after dialysis start, the extraction ratio in the hemodialyser was a factor 1.4-4 lower with MPHD versus SHD, resulting in significantly smaller reduction ratios and lower solute removal within a single session. Even when extrapolating our findings to 3 times $4 \mathrm{~h} \mathrm{SHD}$ and 6 times $8 \mathrm{~h}$ MPHD per week, the latter modality was at best similar in terms of total solute removal for most protein-bound solutes, and worse for the highly protein-bound solutes IS and PCS. When efficiency was calculated as solute removal/litre of dialysate used, MPHD was found superior to SHD.

Conclusion: When high water consumption is a concern, a treatment regimen of 6 times/week $8 \mathrm{~h}$ MPHD might be an alternative for 3 times/week $4 \mathrm{~h} \mathrm{SHD}$, but at the expense of a lower total solute removal of highly protein-bound solutes.

Keywords: Solute removal, Recirculation, Water consumption

\section{Background}

To overcome the non-physiological characteristics of standard 3 times/week 4 hour in-centre hemodialysis, alternative dialysis regimens are being developed, aiming to reduce labour costs and patient burden, and increase patient comfort and solute removal [1-14]. In addition, production of dialysate is being recognized as having an important financial and ecological cost, which is likely to even increase in the future [15]. There is an increasing interest in these alternative renal

\footnotetext{
* Correspondence: sunny.eloot@ugent.be

Deceased

'Department of Nephrology, Ghent University Hospital, De Pintelaan 185, 9000 Ghent, Belgium

Full list of author information is available at the end of the article
}

replacement therapies, whereby either duration of a single session (extended dialysis) [4,7,11,14], the frequency per week (frequent dialysis) $[1,2,6,8,9,13]$ or a combination thereof $[3,12]$ are different from standard 3 times/week dialysis. For most of these settings, regular dialysis monitors are used, with online production of dialysate. Some alternative approaches have been proposed, whereby either dialysate is prepared as a batch [16-18], or is available in industrially prepared bags [19].

Recently, multipass hemodialysis (MPHD) was described as a feasible, economic and ecologic alternative to deliver home hemodialysis [20]. A regime of daily nocturnal dialysis eight hours six times a week, using a dialysate bath of one half of the calculated total body 
water, i.e. 20-25 L, which is continually recycled at a dialysate flow of $500 \mathrm{~mL} / \mathrm{min}$, while blood flow is conventional $(>200 \mathrm{~mL} / \mathrm{min})$ was proposed as treatment paradigm. Obvious advantages are the ease of use, and the low water consumption, making the technique ideal for home hemodialysis. Using this technique, a significantly higher weekly removal was obtained for small water soluble solutes and for middle molecules like $\beta_{2}$ microglobulin, as compared to 3 times $4 \mathrm{~h}$ standard hemodialysis (SHD) [20]. Since higher middle molecule removal has been linked to reduced mortality [21], and due to the limited dialysate consumption, MPHD seems to be a very promising technique for performing (portable) home hemodialysis.

Protein-bound solutes are known as difficult to remove by conventional hemodialysis as the ligand proteins often have a molecular weight above or at the borderline of the cut-off of currently used high flux dialysis membranes. This lack of adequate removal may have important clinical consequences, since several protein-bound solutes have been linked to progression of renal failure, inflammation, vascular disease, and mortality [22-35].

The present study was set up to investigate removal of protein-bound solutes by $8 \mathrm{~h}$ MPHD as compared to 4 h SHD.

\section{Methods \\ Patients}

The patients and methods have been described in a previous publication [20]. Ten stable HD patients, all receiving standard in-centre HD three times per week were included in the original study, but, due to sample corruption, only nine are included in the present study. Exclusion criteria were: age less than 18 years, psychiatric disease, ultrafiltration requirement more than $4 \mathrm{~L}$ per session, possibility of pregnancy and severe comorbidity. Prior to the study, catheter/fistula recirculation was excluded using the indicator dilution technique and the Krivitski method (HD 01 plus, Transonic Systems, Ithaca, New York State). All patients gave written informed consent according to the Helsinki II declaration. The protocol was approved by the local ethics committee 'Videnskabsetiske Komité for Hovedstads Region' (identification number H-2-2009-082) and registered on ClinicalTrials.gov (identification number NCT01267760).

\section{Study design}

Each patient was studied twice with a one week interval. The patients used either the Polyflux $170 \mathrm{H}$ (3 patients) or Polyflux $210 \mathrm{H}$ with a surface area of 1.7 and $2.1 \mathrm{~m}^{2}$, respectively (Gambro, Lund, Sweden) for both sessions. The reference treatment was standard hemodialysis (SHD) lasting 4 hours, with a dialysate flow of $500 \mathrm{~mL} /$ min. The dialysate was continuously collected in a chamber placed on electronic weighing scales. A blender was placed in the chamber to assure adequate mixing before sampling.

The alternative treatment was multipass hemodialysis (MPHD) using a dialysate chamber with a volume corresponding to $50 \%$ of the patient's total body water (TBW), which was estimated as either 55\% (female) or $60 \%$ (male) of dry weight. One patient, with a body weight of $111 \mathrm{~kg}$ and an estimated TBW of $66 \mathrm{~L}$ was only treated with $30.4 \mathrm{~L}$ due to the limitations of the dialysate chamber. The dialysate was prepared by the AK200 dialysis machine (Gambro, Lund, Sweden), and was identical for both treatments. With MPHD, dialysate was recirculated via the chamber which was placed on electronic scales, and in which an oscillation mechanism was installed to assure optimal mixing. Two pumps controlled dialysate inflow $(500 \mathrm{~mL} / \mathrm{min}$ - UF/2) and outflow $(500 \mathrm{~mL} / \mathrm{min}+\mathrm{UF} / 2)$, and thus ultrafiltration (UF). Dialysate temperature was set at $36-37^{\circ} \mathrm{C}$ at the dialyser inlet, and was continuously registered.

Fractionated heparin was used as anticoagulation, at the patient's usual dose (at the start of SHD and MPHD). After 4 hours MPHD a new similar bolus was administered.

\section{Sampling and analysis}

Blood samples were collected from the inlet blood line at the start and at hourly intervals. In addition, one blood sample was taken from the blood outlet line at $60 \mathrm{~min}$ to obtain the dialyser extraction ratio. Blood samples were immediately centrifuged at $3000 \mathrm{rpm}$, after which the plasma was stored at $-80^{\circ} \mathrm{C}$ until batch analysis. From the dialysate chamber, dialysate was sampled hourly and stored at $-80^{\circ} \mathrm{C}$.

Different protein-bound solutes were determined by high performance liquid chromatography (HPLC): pcresylglucuronide (PCG) (molecular weight MW:284 Da, protein binding $\mathrm{PB} \sim 10 \%$ ), hippuric acid (HA - $179 \mathrm{Da}-$ $\mathrm{PB} \sim 50 \%$ ), indole acetic acid (IAA - $175 \mathrm{Da}-\mathrm{PB} \sim 65 \%$ ), indoxyl sulfate (IS - $213 \mathrm{Da}-\mathrm{PB} \sim 90 \%$ ), p-cresylsulfate (PCS - $187 \mathrm{Da}-\mathrm{PB} \sim 95 \%)$. To determine the total concentration, serum samples were first deproteinized by heat denaturation [36] before HPLC analysis. IS and IAA (excitation $\lambda_{\mathrm{ex}}: 280 \mathrm{~nm}$; emission $\lambda_{\mathrm{em}}: 340 \mathrm{~nm}$ ) and PCS and PCG $\left(\lambda_{\text {ex }}: 265 \mathrm{~nm} ; \lambda_{\mathrm{em}}: 290 \mathrm{~nm}\right)$ were determined by fluorescence analysis, and HA by UV detection at $245 \mathrm{~nm}$ [37]. Free fractions were determined according to Fagugli et al. [37] and serum total protein (TP) was analysed according to standard methods.

\section{Calculations}

Reduction ratio ( $R R$ - \%) of solutes was defined as a function of predialysis $\left(\mathrm{C}_{\text {pre }}\right)$ and postdialysis concentrations $\left(C_{\text {post }}\right)$ of samples collected from the inlet blood line: 


$$
\operatorname{RR}(\%)=\frac{C_{\text {pre }}-C_{\text {post }}}{C_{\text {pre }}} \cdot 100
$$

During $8 \mathrm{~h}$ MPHD, RR was also calculated for the 0$240 \mathrm{~min}$ and the 240-480 min dialysis interval.

The dialyser extraction ratio (ER - \%) was calculated as the relative change in concentration from the dialyser inlet $\left(\mathrm{C}_{\text {inlet }}\right)$ towards the outlet $\left(\mathrm{C}_{\text {outlet }}\right)$ :

$$
\operatorname{ER}(\%)=\frac{C_{\text {inlet }}-C_{\text {outlet }}}{C_{\text {inlet }}} \cdot 100
$$

Total solute removal (TSR - mg) at time point $\mathrm{t}$ was calculated from dialysate concentration in the chamber at that time point, and multiplied by either the volume of spent dialysate at time point $\mathrm{t}$ (SHD) or the dialysate volume in the chamber (MPHD). Total solute removal on weekly basis was calculated from TSR as measured

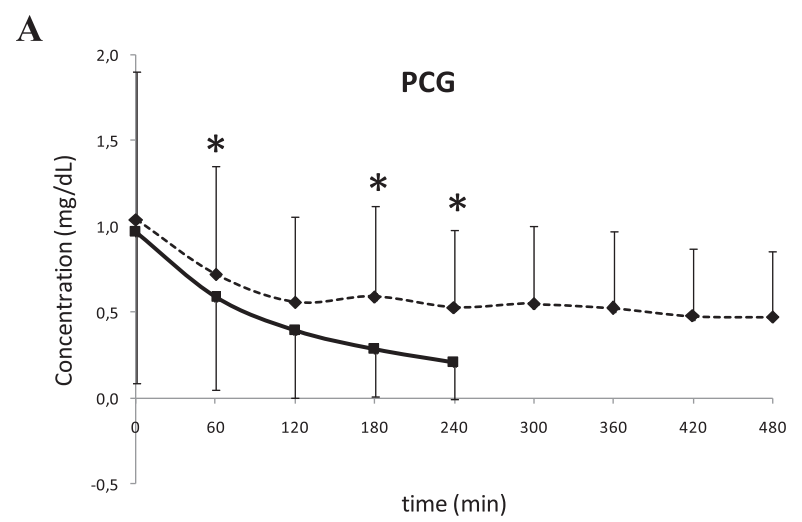

B

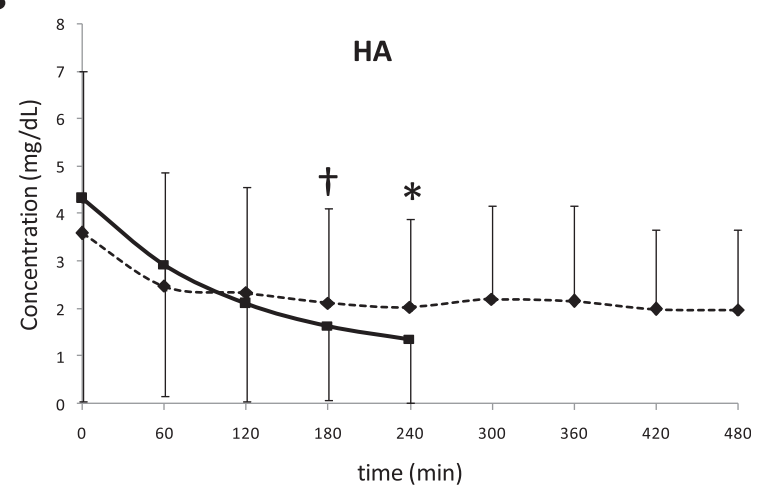

C

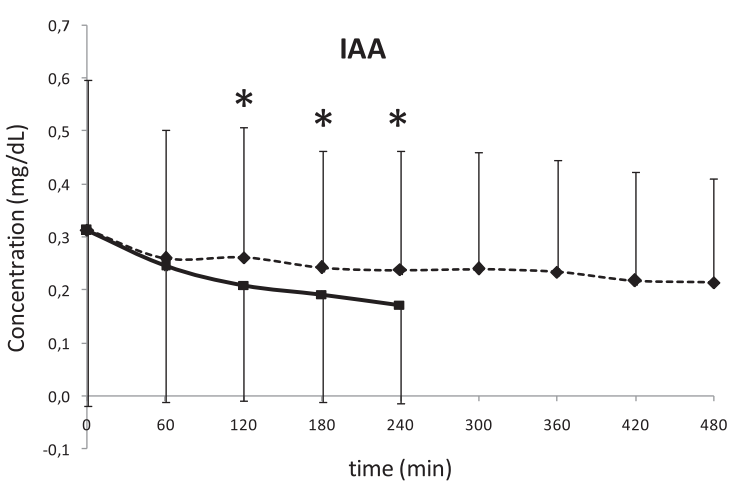

D

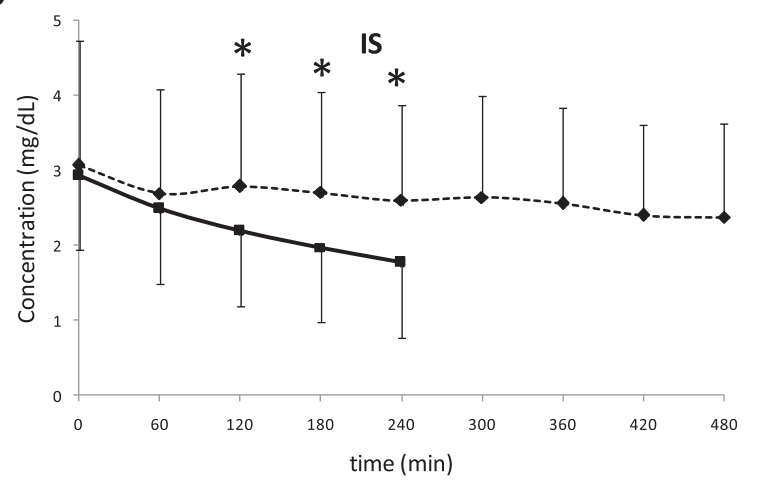

$\mathbf{E}$

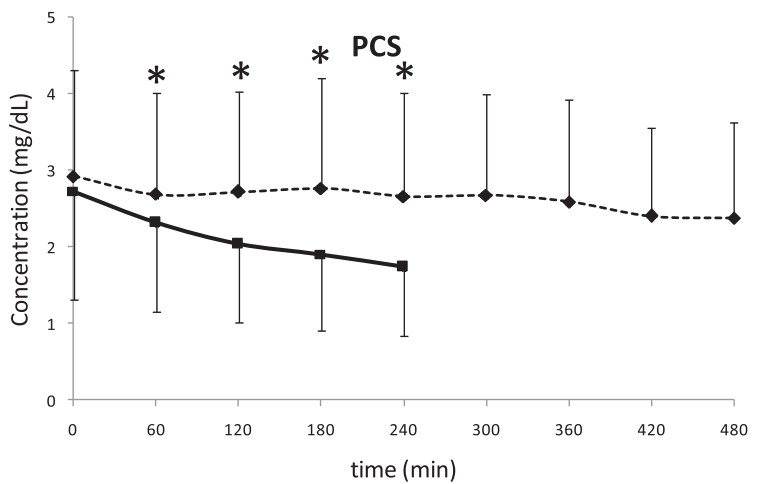

Figure 1 Serum concentrations at different time points during standard hemodialysis SHD (squares - full line) and multipass hemodialysis MPHD (diamonds - dotted line) for p-cresylglucuronide (PCG -panel A), hippuric acid (HA - panel B), indole acetic acid (IAA - panel C), indoxyl sulfate (IS - panel D), and p-cresylsulfate (PCS - panel E). ${ }^{*} \mathrm{P}<0.05 \mathrm{MPHD}$ versus SHD. $+\mathrm{P}=0.053 \mathrm{MPHD}$ versus SHD. 
and calculated in a single session and multiplied by the dialysis frequency per week.

Protein-bound solute concentrations at time point $t$ were corrected for hemoconcentration by a factor (F) based on TP concentration predialysis versus time point $\mathrm{t}: \mathrm{F}=\mathrm{TP}_{\mathrm{pre}} / \mathrm{TP}_{\mathrm{t}}$. Likewise, dialyser outlet concentration $\left(\mathrm{C}_{\text {outlet }}\right)$ was corrected by $\mathrm{F}=\mathrm{TP}_{\text {inlet }} / \mathrm{TP}_{\text {outlet }}$.

\section{Statistical analysis}

Data are expressed as mean $\pm \mathrm{SD}$ assuming normally distributed populations. Statistical analyses were carried out using the parametric $t$-test for paired samples. A $\mathrm{P} \leq 0.05$ was considered to be statistically significant. All statistical analyses were performed using SPSS Statistics 21 (SPSS Inc, Chicago, IL) for Windows (Microsoft Corp, Redmond,WA).

\section{Results}

The nine included patients (female $\mathrm{n}=3$ ) were $63.4 \pm$ 12.7 years old and spent $7.1 \pm 4.4$ years on dialysis. Renal diagnoses were: hypertensive nephropathy $(n=3)$, polycystic renal disease $(n=1)$, glomerulonephritis $(n=1)$, chronic interstitial nephropathy $(\mathrm{n}=1)$, and unknown $(n=3)$. Five patients had a residual daily diuresis of more than $300 \mathrm{~mL} /$ day. Patients dry weight was $79.8 \pm$ $19.4 \mathrm{~kg}$, resulting in a calculated TBW of $46.5 \pm 11.2 \mathrm{~kg}$. Accordingly, MPHD dialysate volume was $22.9 \pm 5.0 \mathrm{~L}$ (range 13.8 to $30.4 \mathrm{~L}$ ). Blood flow was $279 \pm 43 \mathrm{~mL} / \mathrm{min}$ during SHD and $279 \pm 41 \mathrm{~mL} / \mathrm{min}$ during MPHD (N.S.).

Figure 1 illustrates the variation in serum concentration during SHD (squares - full line) and MPHD (diamonds - dotted line) for p-cresylglucuronide (PCG), hippuric acid (HA), indole acetic acid (IAA), indoxyl sulfate (IS), and p-cresylsulfate (PCS). Serum concentrations at start of the dialysis session were not different between both modalities in the individual patients (N.S.). The large standard deviations indicate important interpatient variability in serum concentrations of these solutes. Nevertheless, it was in all patients consistently observed that concentration reductions were much smaller with $8 \mathrm{~h}$ MPHD as compared to $4 \mathrm{~h}$ SHD. In addition, it is noteworthy that during the second half of the $8 \mathrm{~h}$ MPHD, nearly no further change in concentration reduction was observed (Table 1).

Already at $60 \mathrm{~min}$ after dialysis start, a huge difference is observed between the extraction ratio for total and free fractions during SHD and MPHD, due to the recirculation in the latter modality (Table 2). Extraction in the hemodialyser for total concentrations of proteinbound solutes is a factor 1.4-1.8 (PCG, HA, IAA) and 3-4 (IS, PCS) larger with SHD as compared to MPHD, while for the free fractions of these solutes, it is a factor 1.4-1.6 (PCG, HA, IAA) and 2.1-2.5 (IS, PCS). Hence, there is an inverse correlation between extraction ratio
Table 1 Reduction ratios (\%) for different protein-bound solutes in SHD and MPHD

\begin{tabular}{|c|c|c|c|c|}
\hline \multirow[t]{2}{*}{ Solute } & \multirow{2}{*}{$\frac{S H D}{0-240 \min }$} & \multicolumn{3}{|l|}{ MPHD } \\
\hline & & $0-240 \mathrm{~min}$ & $240-480 \mathrm{~min}$ & $0-480 \mathrm{~min}$ \\
\hline$\overline{\text { Total PCG }}$ & $81 \pm 7$ & $51 \pm 5$ & $9 \pm 9+$ & $55 \pm 6^{*}+$ \\
\hline Total HA & $68 \pm 10$ & $42 \pm 7$ & $1 \pm 37 \dagger$ & $43 \pm 16^{*}$ \\
\hline Total IAA & $46 \pm 8$ & $25 \pm 5$ & $9 \pm 13+$ & $32 \pm 8^{*}$ \\
\hline Total IS & $41 \pm 11$ & $14 \pm 6$ & $10 \pm 12$ & $23 \pm 11^{*}+$ \\
\hline Total PCS & $37 \pm 9$ & $10 \pm 9$ & $6 \pm 18$ & $16 \pm 15^{*}$ \\
\hline Free PCG & $84 \pm 5$ & $51 \pm 5$ & $10 \pm 10+$ & $56 \pm 6^{*}+$ \\
\hline Free HA & $78 \pm 8$ & $45 \pm 11$ & $-5 \pm 38 \dagger$ & $44 \pm 16^{*}$ \\
\hline Free IAA & $67 \pm 28$ & $33 \pm 13$ & $8 \pm 21 \dagger$ & $39 \pm 18^{*}$ \\
\hline Free IS & $59 \pm 17$ & $-7 \pm 33$ & $7 \pm 43$ & $-2 \pm 55^{*}$ \\
\hline Free PCS & $74 \pm 11$ & $-1 \pm 44$ & $7 \pm 39$ & $7 \pm 51^{*}$ \\
\hline
\end{tabular}

SHD: standard hemodialysis; MPHD: multipass hemodialysis; PCG: p-cresylglucuronide; HA: hippuric acid; IAA: indole acetic acid; IS: indoxyl sulfate; PCS: p-cresylsulfate.

${ }^{*} \mathrm{P}<0.05$ versus $S H D ;+P<0.05$ versus $M P H D_{0-240 \mathrm{~min}}$.

and percentage protein binding in both SHD $(R=-0.98)$ and MPHD ( $R=-0.99)$, but extraction of highly bound solutes like IS and PCS is even more hampered in MPHD compared to SHD.

Figure 2 clearly indicates that the cumulative total solute removal (TSR) with MPHD versus SHD is, for all studied solutes, much smaller. Of note, TSR seems to saturate after $4 \mathrm{~h}$ MPHD. The normalized TSR for the amount of used dialysate was a factor 3-3.9 (PCG, HA, IAA) and 1.8-1.9 (IS, PCS) larger with MPHD as compared to SHD (Table 3), indicating the relative efficiency of the MPHD modality with regard to water use.

Table 2 Extraction ratios (\%) at 60 min during SHD and MPHD for total and free fractions of different protein-bound solutes

\begin{tabular}{llll}
\hline Solute & SHD & MPHD & SHD/MPHD \\
\hline Total PCG & $73 \pm 15$ & $53 \pm 8^{*}$ & 1.4 \\
Total HA & $54 \pm 10$ & $31 \pm 19^{*}$ & 1.7 \\
Total IAA & $29 \pm 8$ & $16 \pm 8^{*}$ & 1.8 \\
Total IS & $13 \pm 5$ & $5 \pm 5^{*}$ & 2.9 \\
Total PCS & $11 \pm 6$ & $3 \pm 5^{*}$ & 3.9 \\
Free PCG & $78 \pm 10$ & $55 \pm 9^{*}$ & 1.4 \\
Free HA & $65 \pm 11$ & $43 \pm 8^{*}$ & 1.5 \\
Free IAA & $49 \pm 23$ & $31 \pm 12^{*}$ & 1.6 \\
Free IS & $36 \pm 9$ & $17 \pm 10^{*}$ & 2.1 \\
Free PCS & $38 \pm 15$ & $15 \pm 10^{*}$ & 2.5 \\
\hline
\end{tabular}

SHD: standard hemodialysis; MPHD: multipass hemodialysis; PCG: p-cresylglucuronide; HA: hippuric acid; IAA: indole acetic acid; IS: indoxyl sulfate; PCS: $p$-cresylsulfate.

${ }^{*} \mathrm{P}<0.05$ versus SHD. 


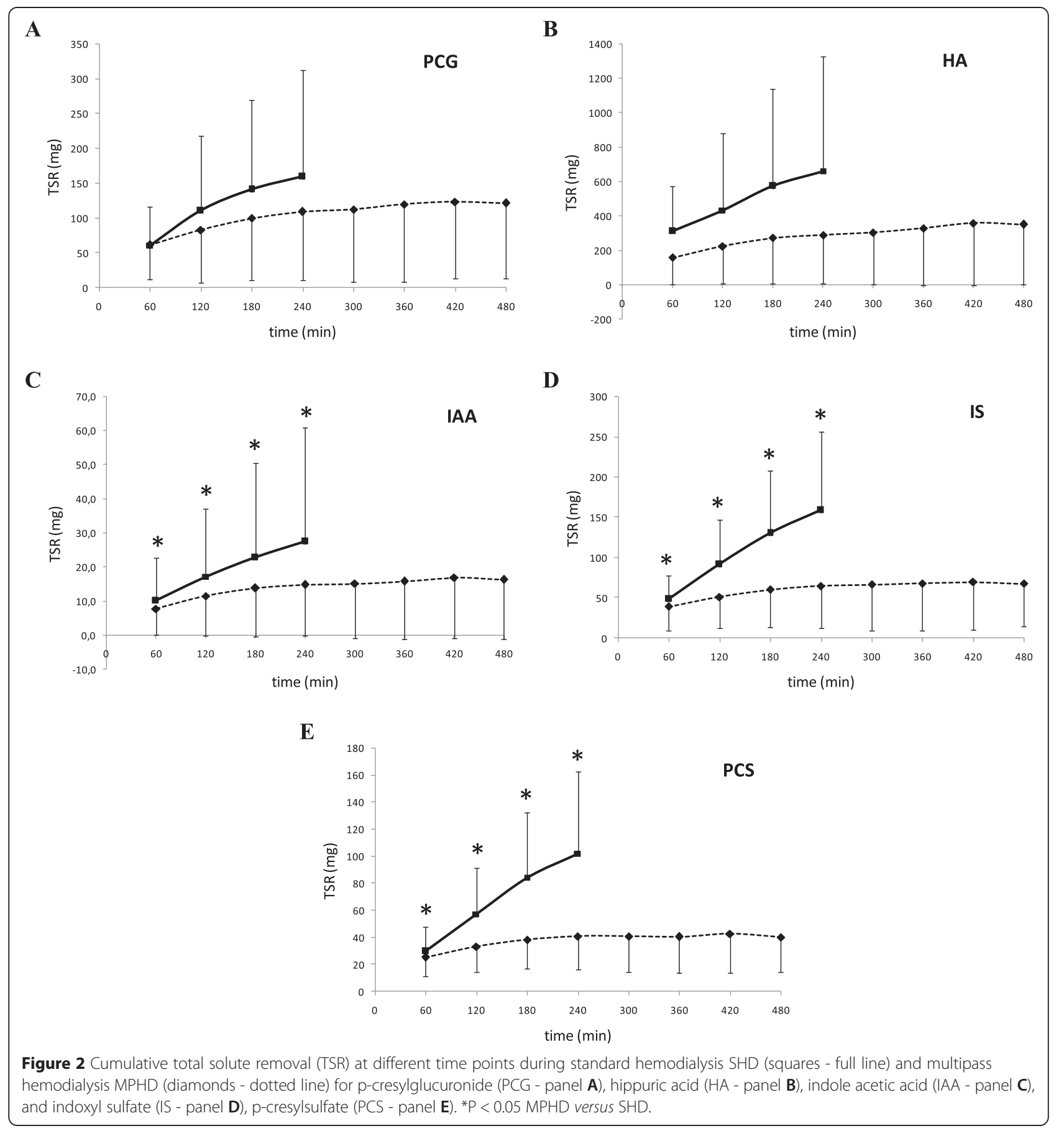

When results of the experimental single session were extrapolated to a weekly basis, the absolute TSR during 6 times 8 h MPHD versus 3 times 4 h SHD was larger for PCG and IAA (Table 4), not different for HA and smaller for IS and PCS. For 6 times 4 h MPHD versus 3 times $4 \mathrm{~h}$ SHD, TSR is only larger for PCG while smaller for IS and PCS, and for 6 times $2 \mathrm{~h}$ MPHD versus 3 times SHD, TSR is significantly smaller for HA, IS, and PCS.

\section{Discussion}

In this cross-over study comparing $4 \mathrm{~h}$ standard hemodialysis (SHD) with $8 \mathrm{~h}$ multipass hemodialysis (MPHD), concentration reduction and total solute removal were assessed for the protein-bound solutes p-cresylglucuronide (PCG), hippuric acid (HA), indole acetic acid (IAA), indoxyl sulfate (IS), and p-cresylsulfate (PCS). We found that already at $60 \mathrm{~min}$ after dialysis start, the extraction ratio in the hemodialyser was a 
Table 3 Total solute removal per litre used dialysate $(\mathrm{mg} / \mathrm{L})$ and the ratio of total solute removal during MPHD versus SHD

\begin{tabular}{|c|c|c|c|c|c|}
\hline \multirow[t]{2}{*}{ Solute } & \multirow{2}{*}{$\frac{S H D}{0-240 \mathrm{~min}}$} & \multicolumn{2}{|l|}{ MPHD } & \multirow[t]{2}{*}{$\frac{\mathrm{MPHD}_{0-240}}{\mathrm{SHD}}$} & \multirow[t]{2}{*}{$\frac{\mathrm{MPHD}_{0-480}}{\mathrm{SHD}}$} \\
\hline & & $0-240 \mathrm{~min}$ & $0-480 \mathrm{~min}$ & & \\
\hline Total PCG & $1.29 \pm 1.22$ & $4.22 \pm 3.57$ & $4.71 \pm 3.93^{*} \dagger$ & $3.6 \pm 1.4$ & $3.9 \pm 1.7$ \\
\hline Total HA & $5.35 \pm 5.39$ & $10.4 \pm 9.2$ & $12.5 \pm 11.3^{*}+$ & $2.7 \pm 1.3$ & $3.0 \pm 1.0$ \\
\hline Total IAA & $0.22 \pm 0.27$ & $0.52 \pm 0.44$ & $0.57 \pm 0.50$ & $3.4 \pm 1.5$ & $3.7 \pm 1.9$ \\
\hline Total IS & $1.29 \pm 0.79$ & $2.43 \pm 1.72$ & $2.54 \pm 1.76^{*}$ & $1.8 \pm 0.6$ & $1.8 \pm 0.7$ \\
\hline Total PCS & $0.83 \pm 0.50$ & $1.60 \pm 0.87$ & $1.56 \pm 0.92^{*}$ & $2.0 \pm 0.9$ & $1.9 \pm 0.9$ \\
\hline
\end{tabular}

SHD: standard hemodialysis; MPHD: multipass hemodialysis; PCG: p-cresylglucuronide; HA: hippuric acid; IAA: indole acetic acid; IS: indoxyl sulfate; PCS: p-cresylsulfate.

${ }^{*} \mathrm{P}<0.05$ versus $\mathrm{SHD} ; \mathrm{P}<0.05$ versus $\mathrm{MPHD}_{0-240 \mathrm{~min}}$.

factor 1.4-4 lower with MPHD versus SHD, resulting in lower reduction ratios and total solute removal. When TSR was calculated per litre of dialysate spent, MPHD appeared to be superior.

It was recently demonstrated that MPHD resulted in superior removal of small and middle molecular weight solutes when applied as 6 times/week 8 h dialysis, an effect that was already demonstrated previously using another batch system (Genius ${ }^{\oplus}$, Fresenius Medical Care) [4]. Our current results add to this knowledge that MPHD applied in this regimen results in equal total solute removal for light and moderately protein-bound solutes, but lower removal for highly protein-bound solutes as compared to standard 3 times weekly hemodialysis. Most likely, this can be explained by the fact that only the free solute can pass across the membrane. As the serum concentration of free solute is rather low, and as the dialysate is recycled, there is a rapid equilibration between the concentrations of the free solute in the serum and in the dialysate. As a result, replenishment of the pool of free toxin in the serum, either by loosening from the protein or by rebound from other compartments, has no effect on solute removal, as the diffusive gradient with the dialysate is lacking. Indeed, we observe (Figure 1) that after some

Table 4 Weekly total solute removal $(\mathrm{mg})$ for 3 times $4 \mathrm{~h}$ SHD, 6 times 2 h MPHD, 6 times 4 h MPHD, and 6 times $8 \mathrm{~h}$ MPHD for different protein-bound solutes

\begin{tabular}{lllll}
\hline Solute & $\mathbf{3 x 4} \mathbf{h} \mathbf{~ S H D}$ & $\mathbf{6 x 2} \mathbf{h} \mathbf{M P H D}$ & $\mathbf{6 x 4} \mathbf{h} \mathbf{M P H D}$ & $\mathbf{6 x 8} \mathbf{h} \mathbf{M P H D}$ \\
\hline Total PCG & $480 \pm 458$ & $498 \pm 452$ & $655 \pm 592^{*}$ & $729 \pm 650^{*}+$ \\
Total HA & $1985 \pm 2010$ & $1338 \pm 1296^{*}$ & $1738 \pm 1688$ & $2104 \pm 2096+$ \\
Total IAA & $83 \pm 101$ & $69 \pm 70$ & $89 \pm 90$ & $98 \pm 105^{*}$ \\
Total IS & $478 \pm 291$ & $308 \pm 232^{*}$ & $388 \pm 314^{*}$ & $406 \pm 320^{*}$ \\
Total PCS & $306 \pm 183$ & $199 \pm 112^{*}$ & $246 \pm 148^{*}$ & $241 \pm 155^{* *}$ \\
\hline
\end{tabular}

SHD: standard hemodialysis; MPHD: multipass hemodialysis; PCG: p-cresylglucuronide; HA: hippuric acid; IAA: indole acetic acid; IS: indoxyl sulfate; PCS: p-cresylsulfate.

${ }^{*} \mathrm{P}<0.05$ versus $3 \times 4 \mathrm{~h}$ SHD; ${ }^{* *} \mathrm{P}=0.57$ versus $3 \times 4 \mathrm{~h}$ SHD; $+\mathrm{P}<0.05$ versus $6 \times 4$ h MPHD. hours of dialysis, there is a plateau of the concentration in the dialysate, and accordingly, a significantly lower extraction ratio in the hemodialyser is observed already after $60 \mathrm{~min}$. After this, no further solute removal is observed. The timing of this plateau phase comes more early as the solute is more strongly protein-bound. Extending the dialysis session is accordingly of no use to increase solute removal of protein-bound toxins when small volumes of dialysate are recycled.

For middle molecular structures such as $\beta_{2}$-microglobulin, this diffusive transport over the dialysis membrane is much slower, so the equilibration/saturation is also occurring at a slower rate. An increase of dialysis time from 4 to 8 hours, maintaining the same amount of processed blood and dialysate, previously demonstrated a $81 \%$ higher $\beta_{2}$-microglobulin removal, a phenomenon that was much less pronounced (26-36\% increase) for the small water soluble solutes urea and creatinine [4]. This effect can be attributed to the slow transport of $\beta_{2}$-microglobulin between the extraplasmatic and plasmatic compartment [38,39], resulting in a substantial rebound after conventional and short hemodialysis [40]. During extended dialysis, the solute is allowed more time to shift between compartments. Accordingly, extending the dialysis session allows the serum pool of the middle molecule to be replenished from other compartments, resulting in an increase in solute removal even when recycling the dialysate, as demonstrated previously [20].

A limitation of our study might be the mathematical extrapolation of the removal during a single session to the removal on weekly basis. Theoretically, since predialysis concentrations of toxins can be decreased in frequent dialysis, solute removal could be overestimated with frequent MPHD. However, as we are dealing with protein-bound solutes, only the free fraction can be eliminated during the dialysis session such that total removal is very low. Hence, it is likely that this free fraction is completely restored during the interdialytic interval, which was also found by Fagugli et al. investigating removal of protein-bound 
solutes in short daily dialysis (6 times weekly 2 hours) as compared to standard hemodialysis (3 times weekly 4 hours), even with a regular dialysis monitor and dialysate flow, so that saturation of dialysate could not play a role [37].

It could be hypothesized that in order to increase solute removal of protein-bound toxins, one needs to extend total weekly treatment time, and use sufficiently high ratio of dialysate to blood flow. A recent kinetic analysis supported this hypothesis [41]. If it is intended to use recycling of dialysate, an absorbent should be added to the dialysate system to keep the concentration of the free fraction of protein-bound solutes as low as possible.

Although it appears that MPHD is less suitable than SHD to remove protein-bound solutes, the advantage of MPHD is mainly the relatively higher amount of solute removed per litre of dialysate (Table 3 ). This makes the multipass system a suitable alternative to apply in the setting of daily extended dialysis at home [42], where the classical setup implies substantial technical modifications and results in a high consumption of water and electricity. The economy in water consumption is $33 \%$ (240 L/week versus $360 \mathrm{~L} /$ week), as more frequent dialysis is needed. Whereas this seems an impressive saving, we need to realize that water consumption is with 4-11\% only a limited part of the carbon foot print of dialysis treatment, as compared to $35.7 \%$ for pharmaceuticals and $23.4 \%$ for medical equipment.

\section{Conclusion}

MPHD appears to have some interesting features for use in the home setting, and results in more efficient use of dialysate. However, the currently proposed regimen of 6 times/week 8 hours seems to have no advantage over 3 times/week SHD in terms of removal of protein-bound solutes.

\section{Abbreviations \\ C: Concentration; ER: Extraction ratio; HA: Hippuric acid; HD: Hemodialysis; HPLC: High performance liquid chromatography; IAA: Indole acetic acid; IS: Indoxyl sulfate; MPHD: Multipass hemodialysis; N.S.: Non significant; PB: Protein binding; PBS: Protein-bound solutes; PCG: p-cresylglucuronide; PCS: p-cresylsulfate; RR: Reduction ratio; SHD: Standard hemodialysis (PBS); TBW: Total body water; TP: Total protein; TSR: Total solute removal; UF: Ultrafiltration.}

\section{Competing interests}

RSP formerly owned shares in Flexdialysis ApS. However, R.S.P. died before the manuscript could be completed. The other authors declare that they have no competing interests.

\section{Authors' contributions}

SE analysed and interpreted the data, performed the statistical analysis, and drafted the manuscript. WVB interpreted the data and co-drafted the manuscript. MA participated in the design and the execution of the study. GG coordinated the analytical determinations and interpreted the data. RSP participated in the design and the execution of the study. JH participated in the design of the study and has given final approval of the version to be published. All authors (except RSP who died previously) read and approved the final manuscript.

\section{Authors' information}

Unfortunately, RSP, who was a major contributor to the conduct of this investigation, died before the manuscript could be completed.

\section{Acknowledgements}

R.S.P. earned consulting honoraria from Flexdialysis $A / S$. The authors are indebted to the laboratory staff M. Van Landschoot, M.A. Waterloos, and S. Lobbestael for their technical assistance.

\section{Author details}

'Department of Nephrology, Ghent University Hospital, De Pintelaan 185, 9000 Ghent, Belgium. ${ }^{2}$ Institute of Public Health, Aarhus University, Nordre Ringgade 1, 8000 Aarhus C, Denmark. ${ }^{3}$ Flexdialysis Aps, Copenhagen, Denmark. ${ }^{4}$ Department of Nephrology, Herlev Hospital, University of Copenhagen, Copenhagen, Denmark.

Received: 12 January 2015 Accepted: 15 April 2015

Published online: 18 April 2015

\section{References}

1. Ayus JC, Mizani MR, Achinger SG, Thadhani R, Go AS, Lee S. Effects of short daily versus conventional hemodialysis on left ventricular hypertrophy and inflammatory markers: a prospective, controlled study. J Am Soc Nephrol. 2005;16:2778-88.

2. Chertow GM, Levin NW, Beck GJ, Depner TA, Eggers PW, Gassman JJ, et al. In-center hemodialysis six times per week versus three times per week. N Engl J Med. 2010;363:2287-300.

3. Culleton BF, Walsh M, Klarenbach SW, Mortis G, Scott-Douglas N, Quinn RR, et al. Effect of frequent nocturnal hemodialysis vs conventional hemodialysis on left ventricular mass and quality of life: a randomized controlled trial. JAMA. 2007:298:1291-9.

4. Eloot S, Van Biesen W, Dhondt A, Van de Wynkele H, Glorieux G, Verdonck $P$, et al. Impact of hemodialysis duration on the removal of uremic retention solutes. Kidney Int. 2008;73:765-70.

5. Eloot S, Van Biesen W, Dhondt A, De Smet R, Marescau B, De Deyn PP, et al. Impact of increasing haemodialysis frequency versus haemodialysis duration on removal of urea and guanidino compounds: a kinetic analysis. Nephrol Dial Transplant. 2009;24:2225-32.

6. Hall YN, Larive B, Painter P, Kaysen GA, Lindsay RM, Nissenson AR, et al. Effects of six versus three times per week hemodialysis on physical performance, health, and functioning: Frequent Hemodialysis Network (FHN) randomized trials. Clin J Am Soc Nephrol. 2012;7:782-94.

7. Hanly PJ, Pierratos A. Improvement of sleep apnea in patients with chronic renal failure who undergo nocturnal hemodialysis. N Engl J Med. 2001;344:102-7.

8. Jaber BL, Schiller B, Burkart JM, Daoui R, Kraus MA, Lee Y, et al. Impact of short daily hemodialysis on restless legs symptoms and sleep disturbances. Clin J Am Soc Nephrol. 2011;6:1049-56.

9. Maduell F, Navarro V, Torregrosa E, Rius A, Dicenta F, Cruz MC, et al. Change from three times a week on-line hemodiafiltration to short daily on-line hemodiafiltration. Kidney Int. 2003;64:305-13.

10. McFarlane PA, Bayoumi AM, Pierratos A, Redelmeier DA. The quality of life and cost utility of home nocturnal and conventional in-center hemodialysis. Kidney Int. 2003;64:1004-11.

11. Ok E, Duman S, Asci G, Tumuklu M, Onen SO, Kayikcioglu M, et al. Comparison of 4- and 8-h dialysis sessions in thrice-weekly in-centre haemodialysis: a prospective, case-controlled study. Nephrol Dial Transplant. 2011;26:1287-96

12. Rocco MV, Lockridge Jr RS, Beck GJ, Eggers PW, Gassman JJ, Greene T, et al. The effects of frequent nocturnal home hemodialysis: the Frequent Hemodialysis Network Nocturnal Trial. Kidney Int. 2011;80:1080-91.

13. Ting GO, Kjellstrand C, Freitas T, Carrie BJ, Zarghamee S. Long-term study of high-comorbidity ESRD patients converted from conventional to short daily hemodialysis. Am J Kidney Dis. 2003;42:1020-35.

14. Walsh M, Manns BJ, Klarenbach S, Tonelli M, Hemmelgarn B, Culleton B. The effects of nocturnal compared with conventional hemodialysis on mineral metabolism: A randomized-controlled trial. Hemodial Int. 2010;14:174-81. 
15. Vanholder R, Eloot S, Van Biesen W, Lameire N. Less water for haemodialysis: is multiple pass the future pace to go? Nephrol Dial Transplant. 2013;28:1067-70

16. Eloot S, Dhondt A, Vierendeels J, De Wachter D, Verdonck P, Vanholder R. Temperature and concentration distribution within the Genius dialysate container. Nephrol Dial Transplant. 2007;22:2962-9.

17. Fassbinder W. Experience with the GENIUS hemodialysis system. Kidney Blood Press Res. 2003;26:96-9.

18. Dhondt AW, Vanholder RC, De Smet RV, Claus SA, Waterloos MA, Glorieux $G L$, et al. Studies on dialysate mixing in the Genius single-pass batch system for hemodialysis therapy. Kidney Int. 2003;63:1540-7.

19. Clark WR, Turk Jr JE. The NxStage system one. Semin Dial. 2004;17:167-70.

20. Heaf JG, Axelsen M, Pedersen RS. Multipass haemodialysis: a novel dialysis modality. Nephrol Dial Transplant. 2013;28:1255-64.

21. Santoro A, Mancini E, Bolzani R, Boggi R, Cagnoli L, Francioso A, et al. The effect of on-line high-flux hemofiltration versus low-flux hemodialysis on mortality in chronic kidney failure: a small randomized controlled trial. Am J Kidney Dis. 2008:52:507-18.

22. Vanholder R, De Smet R. Pathophysiologic effects of uremic retention solutes. J Am Soc Nephrol. 1999;10:1815-23.

23. Vanholder R, Baurmeister U, Brunet P, Cohen G, Glorieux G, Jankowski J. A bench to bedside view of uremic toxins. J Am Soc Nephrol. 2008;19:863-70.

24. Adijiang A, Goto S, Uramoto S, Nishijima F, Niwa T. Indoxyl sulphate promotes aortic calcification with expression of osteoblast-specific proteins in hypertensive rats. Nephrol Dial Transplant. 2008;23:1892-901.

25. Bammens B, Evenepoel $P$, Keuleers $H$, Verbeke $K$, Vanrenterghem $Y$. Free serum concentrations of the protein-bound retention solute $\mathrm{p}$-cresol predict mortality in hemodialysis patients. Kidney Int. 2006;69:1081-7.

26. Barreto FC, Barreto DV, Liabeuf S, Meert N, Glorieux G, Temmar M, et al. Serum indoxyl sulfate is associated with vascular disease and mortality in chronic kidney disease patients. Clin J Am Soc Nephrol. 2009;4:1551-8

27. Dou L, Bertrand E, Cerini C, Faure V, Sampol J, Vanholder R, et al. The uremic solutes $\mathrm{p}$-cresol and indoxyl sulfate inhibit endothelial proliferation and wound repair. Kidney Int. 2004;65:442-51.

28. Liabeuf S, Barreto DV, Barreto FC, Meert N, Glorieux G, Schepers E, et al. Free p-cresylsulphate is a predictor of mortality in patients at different stages of chronic kidney disease. Nephrol Dial Transplant. 2010;25:1183-91.

29. Meijers BK, Bammens B, De Moor B, Verbeke K, Vanrenterghem Y, Evenepoel $P$. Free $p$-cresol is associated with cardiovascular disease in hemodialysis patients. Kidney Int. 2008;73:1174-80.

30. Meijers BK, Van Kerckhoven S, Verbeke K, Dehaen W, Vanrenterghem Y, Hoylaerts MF, et al. The uremic retention solute p-cresyl sulfate and markers of endothelial damage. Am J Kidney Dis. 2009;54:891-901.

31. Niwa T, Takeda N, Tatematsu A, Maeda K. Accumulation of indoxyl sulfate, an inhibitor of drug-binding, in uremic serum as demonstrated by internal-surface reversed-phase liquid chromatography. Clin Chem. 1988;34:2264-7.

32. Schepers E, Meert N, Glorieux G, Goeman J, der EJ V, Vanholder R. Pcresylsulphate, the main in vivo metabolite of p-cresol, activates leucocyte free radical production. Nephrol Dial Transplant. 2007;22:592-6.

33. Yamamoto H, Tsuruoka S, loka T, Ando H, Ito C, Akimoto T, et al. Indoxyl sulfate stimulates proliferation of rat vascular smooth muscle cells. Kidney Int. 2006;69:1780-5.

34. Yu MA, Sanchez-Lozada LG, Johnson RJ, Kang DH. Oxidative stress with an activation of the renin-angiotensin system in human vascular endothelial cells as a novel mechanism of uric acid-induced endothelial dysfunction. J Hypertens. 2010;28:1234-42.

35. Zoccali C, Maio R, Mallamaci F, Sesti G, Perticone F. Uric acid and endothelial dysfunction in essential hypertension. J Am Soc Nephrol. 2006;17:1466-71

36. Vanholder R, Hoefliger N, De SR, Ringoir S. Extraction of protein bound ligands from azotemic sera: comparison of 12 deproteinization methods. Kidney Int. 1992;41:1707-12.

37. Fagugli RM, De Smet R, Buoncristiani U, Lameire N, Vanholder R. Behavior of non-protein-bound and protein-bound uremic solutes during daily hemodialysis. Am J Kidney Dis. 2002;40:339-47.

38. Odell RA, Slowiaczek P, Moran JE, Schindhelm K. Beta 2-microglobulin kinetics in end-stage renal failure. Kidney Int. 1991;39:909-19.

39. Stiller S, Xu XQ, Gruner N, Vienken J, Mann H. Validation of a two-pool model for the kinetics of beta2-microglobulin. Int J Artif Organs. 2002;25:411-20
40. Leypoldt JK, Cheung AK, Deeter RB. Rebound kinetics of beta2microglobulin after hemodialysis. Kidney Int. 1999;56:1571-7.

41. Eloot S, Vanholder R. Kinetics of protein-bound solutes during hemodialysis. Int J Artif Organs. 2012;35(8):583.

42. Vanholder R, Eloot S, Neirynck N, Van Biesen W. Home haemodialysis and uraemic toxin removal: does a happy marriage exist? Nat Rev Nephrol. 2012;8:579-88

\section{Submit your next manuscript to BioMed Central and take full advantage of:}

- Convenient online submission

- Thorough peer review

- No space constraints or color figure charges

- Immediate publication on acceptance

- Inclusion in PubMed, CAS, Scopus and Google Scholar

- Research which is freely available for redistribution 